\title{
MEMBANGUN PENDIDIKAN KARAKTER GENERASI MUDA MELALUI BUDAYA KEARIFAN LOKAL DI ERA GLOBAL
}

\author{
Satrijo Budiwibowo *
}

\begin{abstract}
The parameter of the nation's achievement is that of youth in the future, because maintaining the achievement is usually more difficult than fighting for it. Youth are young generation who are ablidged to maintain leadership and struggle to stay fit around the stricker competition in all aspects due to the higher velocity of service capital throughout the world, which influence the national integrity of a nation. This can only be resolved by producing human resource with high competitive advantage. Globalization has become the term to call a world condition which takes place without boreder. The globalization progress has evidently stood aside local wisdoms of a nation. This article serves an aoutlook on the efforts of universal character building which is rooted from the local wisdom.
\end{abstract}

Keywords: Character Education, Local Wisdom

\begin{abstract}
Abstrak
Tolok ukur keberhasilan suatu negara atau bangsa adalah keberhasilan generasi muda dimasa yang akan datang, karena mempertahankan keberhasilan biasanya lebih sulit dari pada merebut keberhasilan itu sendiri. Generasi muda merupakan penerus tongkat estafet kepemimpinan, perjuangan untuk tetap berdiri kokoh, seiring dengan tugas tersebut, kompetisi diberbagai bidang juga semakin tinggi yang disebabkan oleh derasnya arus perputaran modal jasa keseluruh pelosok dunia yang mempengaruhi integritas nasional, kesemuanya hanya mungkin dijalani dengan kualitas kompetensi yang berdaya saing tinggi. Globalisasi merupakan konsep yang banyak digunakan untuk merespon kondisi dunia yang tanpa batas atau sekat. Salah satu realitas yang harus selalu dikritisi untuk menyikapi globalisasi adalah bahwa globalisasi dengan modernisasi ternyata telah menggerus bahkan telah mematikan nilai-nilai kearifan lokal suatu daerah. Dalam rangka membangun pendidikan karakter bangsa melalui budaya kerarifan lokal perlu dilakukan pengkajian, dan pengembangan karakter dengan fokus menanamkan pada pilar nilai-nilai luhur universal.

Kata kunci: Pendidikan Karakter, Kearifan Lokal
\end{abstract}

* Satrijo Budiwibowo adalah Dosen Prodi Pendidikan Akuntansi dan Ketua LPPM IKIP PGRI Madiun 


\section{A. PENDAHULUAN}

Sebuah bangsa adalah kumpulan dari perilaku (behaviour) atau tata nilai (values). Sendi sendi yang menopang sebuah bangsa pada umumnya adalah berupa karakter dan mentalitas rakyatnya yang menjadi pondasi yang kukuh dari tata nilai bangsa tersebut. Keruntuhan sebuah bangsa umumnya ditandai dengan semakin lunturnya nilai - nilai budaya bangsa dan terbelahnya budaya kearifran lokal walaupun secara fisik keberadaan bangsa tersebut masih eksis dan diakui. Membangun bangsa dengan mengoptimalisasikan peran generasi muda dalam kompetisi global (global advantage) tidak terlepas dari peran serta pemerintah, lembaga kepemudaan dan organisasi kepemudaan ataupun organisasi masyarakat lainnya. Lebih-lebih peran lembaga atau institusi perguruan tinggi, yang sarat dengan idealisme dan cita-cita, sebagaimana cita-cita dan tujuan nasional yang tak pernah berakhir (never ending). Sebagai pewaris tongkat estafet generasi muda perlu diperhatikan dan dibina.

Tolok ukur keberhasilan suatu negara atau bangsa adalah keberhasilan generasi muda dimasa yang akan datang, karena mempertahankan keberhasilan biasanya lebih sulit dari pada merebut keberhasilan itu sendiri. Generasi muda merupakan penerus tongkat estafet kepemimpinan, perjuangan untuk tetap berdiri kokoh, seiring dengan tugas tersebut, kompetisi diberbagai bidang juga semakin tinggi yang disebabkan oleh derasnya arus perputaran modal jasa keseluruh pelosok dunia yang mempengaruhi integritas nasional, kesemuanya hanya mungkin dijalani dengan kualitas kompetensi yang berdaya saing tinggi.

Sehubungan dengan peran generasi muda sebagai salah satu komponen bangsa yang paling rentan dalam proses amalgamasi tata nilai dan budaya, maka pada era Abad 21 ini, secara khusus diberikan ulasan tentang peran kritis generasi muda dalam pembangunan dan pemberdayaan karakter bangsa (character building) berdasarkan kearifan lokal (local wisdom), yang menunjang pada kemandirian bangsa ditengah terpaan arus globalisasi.

\section{B. PEMBAHASAN}

\section{Tantangan Bangsa Indonesia di Tengah Globalisasi}

Tantangan yang sedang dihadapi bangsa Indonesia sekarang ini adalah: (1) nasionalisme dan pluralisme bangsa dipertanyakan dan bahkan identitas nasional dipersoalkan; (2) krisis global, yang secara luas berdampak negatif ke setiap sektor; (3) primordialisme, tuntutan-tuntutan plural yang mengesampingkan integritas bangsa dan menonjolkan kepentingan kelompok atau semangat kedaerahan yang diwarnai ketidak pedulian nasib bangsa; (4) krisis moral, merebaknya berbagai persoalan masyarakat, yang membuat rasional politik anak negeri menjadi melemah, kepedulian sosial rendah, dan menjadi ladang subur tumbuhnya kriminal; (5) krisis ketauladanan, realitas menunjukkan bahwa ketauladanan dari para elite baik nasional maupun lokal saat ini sangat langka, pada hal sebagai generasi penerus bercermin kepada tokoh-tokoh pemimpinnya, baik formal maupun informal; (6) krisis sosial budaya muncul dalam berbagai bentuk disorientasi dan dislokalisasi dibanyak kalangan masyarakat yang disebabkan euforia kebebasan yang kebablasan, lenyapnya kesabaran sosial menghadapi kehidupan yang semakin sulit; (7) tingkat kompetisi yang tinggi, tantangan kompetisi dan peluang semakin selektif; dan (8) karakter bangsa yang semakin samar (abu-abu), akibat pengaruh global. 
Berkembangnya prilaku baru yang sebelum era global tidak banyak muncul, kini cenderung meluas, yakni: (1) meningkatnya kekerasan di kalangan masyarakat; (2) penggunaan bahasa dan kata-kata yang memburuk, cenderung tidak menggunakan kata baku; (3) pengaruh peer-group (geng) yang kuat dalam tindak kekerasan; (4) meningkatnya perilaku merusak diri, seperti penggunaan narkoba, alkohol; (5) semakin kaburnya pedoman moral baik dan buruk; (6) menurunnya etos kerja; (7) semakin rendahnya rasa hormat kepada orangtua dan guru; (8) rendahnya rasa tanggung jawab individu dan warga negara; (9) membudayanya ketidakjujuran; dan (10) adanya rasa saling curiga dan kebencian di antara sesama. Disisi lain adanya masyarakat kita yang sangat sibuk mencari kehidupan duniawi, mengejar harta dan tahta, hingga tega menyerahkan pendidikan dan pengasuhan balita kepada pembantu yang notabene kurang memiliki cukup kemampuan sebagai pendidik. Ketika masa remaja tidak terperhatikan, bahkan pembinaan remaja di luar sekolah maupun di rumah diserahkan kepada masyarakat, yang ternyata kondisinya tidak kondusif bagi pengembangan karakter. Bahkan sampai masa dewasa, integrasi masyarakat tidak menentu, saling tidak mempercayai (trust), kehidupan semu, tidak tulus, Asal Bapak Senang, budaya munafik. Jadi ada sesuatu yang hilang (nothing to loose) yaitu karakter dan kearifan lokal.

Dunia semakin mengglobal dengan munculnya fenomena pola hubungan masyarakat yang mendunia yang ditandai oleh kian minimnya sekat atau batas negara (bordeless world). Karena itu perlu mempersiapkan generasi muda yang berjiwa nasionalis-patriotis, cerdas, jujur dan bertanggung jawab (young generations stronght future), melalui pendidikan karakter yang menjunjung nilainilai budaya kearifan lokal. Meskipun sudah bukan barang baru, namun harus diakui, bahwa fenomena globalisasi adalah dinamika yang paling strategis dan membawa pengaruh dalam tata nilai dari berbagai bangsa termasuk bangsa Indonesia. Sebagian kalangan menganggapnya sebagai ancaman yang berpotensi untuk menggulung karakter bangsa dan budaya lokal, tata nilai dan tradisi bangsa kita, malah menggantinya dengan tata nilai yang bercorak pragmatisme dan populerisme asing yang jelas-jelas tidak sesuai dengan kepribadian bangsa kita. Di pihak lain, globalisasi adalah juga sebuah fenomena alami, sebuah fragmen dari perkembangan proses peradaban yang harus kita lalui bersama. Sehubungan dengan hal tersebut, maka pada makalah ini layak dijadikan sebagai acuan untuk mengulas pembangunan karakter bangsa dengan selalu memperhatikan budaya kearifan lokal, agara khasanah budaya yang beraneka ragam di bumi pertiwi ini tetap utuh terjaga.

\section{Perlunya Pendidikan Karakter dalam Perspektif Budaya Kearifan Lokal}

Pendidikan sebagai proses humanisasi lebih menitikberatkan kepada peran manusia sebagai makhluk sosial yang memiliki otonomi moral dan sensivitas budaya. Artinya bahwa manusia sebagai makhluk individu sekaligus sebagai makhluk sosial harus bisa dan mampu mengelola konflik serta menghargai kemajukan berbagai budaya. Toleransi dan transformasi budaya harus dipandu pelan-pelan, bukan merupakan revolusi sosial yang dipaksakan. Secara universal diakui kedudukan dan martabat manusia sebagai dinyatakan: these values be democratically shared in a world-wide order, resting on respect for human dignity as a supervalue (Bodenheimer 1962: 143). Sebagaimana juga Kant 
menyatakan: that humanity should always be respected as an end itself (McCoubrey dan White 1996: 84).

Tantangan globalisasi dan proses demokrasi yang semakin kuat dan beragam disatu pihak, dan dunia pendidikan sepertinya lebih mementingkan penguasaan dimensi pengetahuan (kognitif) saja dan mengabaikan pendidikan nilai/moral (afektif), merupakan alasan yang kuat bagi bangsa Indonesia untuk membangkitkan komitmen dan melakukan pendidikan karakter berdasarkan kearifan lokal. Pendidikan karakter bangsa diharapkan mampu menjadi alternatif solusi untuk mengatasi berbagai persoalan. Kondisi dan situasi saat ini tampaknya menuntut pendidikan karakter yang perlu ditransformasikan sejak dini, yakni sejak pendidikan anak usia dini, pendidikan dasar, pendidikan menengah dan pendidikan tinggi secara holistik dan berkesinambungan.

Secara historis-geneologis, pencetus pendidikan karakter yang menekankan dimensi etis-spiritual dalam proses pembentukan pribadi ialah pedagog Jerman, Foerster. Ada empat ciri dasar dalam pendidikan karakter menurut Foerster. Pertama, keteraturan interior dengan setiap tindakan diukur berdasar hierarki nilai. Nilai menjadi pedoman normatif setiap tindakan. Kedua, koherensi yang memberi keberanian, membuat seseorang teguh pada prinsip, tidak mudah terombang-ambing pada situasi baru atau takut risiko. Koherensi merupakan dasar yang membangun rasa percaya satu sama lain. Tidak adanya koherensi meruntuhkan kredibilitas seseorang. Ketiga, otonomi. Di situ seseorang menginternalisasikan aturan dari luar sampai menjadi nilai-nilai bagi pribadi. Itu dapat dilihat lewat penilaian atas keputusan pribadi tanpa terpengaruh oleh atau desakan dari pihak lain. Keempat, keteguhan dan kesetiaan. Keteguhan merupakan daya tahan seseorang guna mengingini apa yang dipandang baik. Kesetiaan merupakan dasar bagi penghormatan atas komitmen yang dipilih. Karakter itulah yang menentukan bentuk seorang pribadi dalam segala tindakannya.

Selain itu pendidikan karakter adalah suatu sistem penanaman nilai-nilai karakter kepada warga sekolah yang meliputi komponen pengetahuan, kesadaran atau kemauan, dan tindakan untuk melaksanakan nilai-nilai tersebut. Pendidikan karakter dapat dimaknai sebagai: the deliberate use of all dimensions of school life to foster optimal character development. Menurut Philips (2008:235) karakter adalah kumpulan tata nilai yang menuju pada suatu sistem, yang melandasi pemikiran, sikap, dan perilaku yang ditampilkan. Sedangkan Koesoema (2007:80) memahami bahwa karakter sama dengan kepribadian. Kepribadian dianggap sebagai ciri, atau karakteristik, atau gaya, atau sifat khas dari diri seseorang yang bersumber dari bentukan-bentukan yang diterima dari lingkungan, misalnya lingkungan keluarga pada masa kecil dan juga bawaan seseorang sejak lahir. Karakter bangsa sebagai kondisi watak yang merupakan identitas bangsa. Menurut Elkind dan Sweet (2004):

Character education is the deliberate effort to help people understand, care about, and act upon core ethical values. When we think about the kind of character we want for our children, it is clear that we want them to be able to judge what is right, care deeply about what is right, and then do what they believe to be right, even in the face of pressure from without and temptation from within. 
Sedangkan Ghozali menganggap bahwa karakter lebih dekat dengan akhlaq, yaitu spontanitas manusia dalam bersikap, atau melakukan perbuatan yang telah menyatu dalam diri manusia sehingga ketika muncul tidak perlu dipikirkan lagi. Dengan demikian dapat disimpulkan bahwa karakter itu berkaitan dengan kekuatan moral, berkonotasi "positif", bukan netral. Jadi orang berkarakter adalah orang yang mempunyai kualitas moral (tertentu) positif. Dengan demikian, pendidikan membangun karakter, secara implisit mengandung arti membangun sifat atau pola perilaku yang didasari atau berkaitan dengan dimensi moral yang positif atau baik, bukan yang negatif atau buruk. Hal ini didukung oleh Peterson dan Seligman yang mengaitkan secara langsung character strength dengan kebajikan (Raka, 2007:5). Character strength dipandang sebagai unsur-unsur psikologis yang membangun kebajikan (virtues). Salah satu kriteria utama dari character strength adalah bahwa karakter tersebut berkontribusi besar dalam mewujudkan sepenuhnya potensi dan cita-cita seseorang dalam membangun kehidupan yang baik, yang bermanfaat bagi dirinya, orang lain, dan bangsanya.

Masyarakat Indonesia dan budayanya yang plural (jamak) dan heterogen (aneka ragam) mencerminkan kebhinekaan yang manunggal. Pluralitas sebagai kontradiksi dari singularitas mengindikasikan adanya suatu situasi yang terdiri dari kejamakan, yaitu dijumpainya berbagai subkelompok masyarakat yang tidak bisa di satu kelompokkan satu dengan yang lainnya, demikian pula dengan kebudayaan mereka, sementara heterogenitas merupakan kontraposisi dari homogenitas mengindikasi suatu kualitas dari keadaan yang menyimpan ketidak samaan dalam unsur-unsurnya. Sejarah menunjukkan, masing-masing etnis dan suku memiliki kearifan lokal sendiri. Misalnya saja (untuk tidak menyebut yang ada pada seluruh suku dan etnis di Indonesia), suku Batak kental dengan keterbukaan, Jawa identik dengan kehalusan, suku Bugis dan Madura memiliki harga diri yang tinggi, dan etnis Cina terkenal dengan keuletan. Lebih dari itu, masing-masing memiliki keakraban dan keramahan dengan lingkungan alam yang mengitari mereka.

Pengertian kearifan lokal dilihat dari Kamus Inggris-Indonesia, terdiri dari 2 kata yaitu kearifan (wisdom) dan lokal (local). Local berarti setempat dan wisdom sama dengan kearifan. Dengan kata lain maka local wisdom dapat dipahami sebagai gagasan-gagasan, nilai-nilai-nilai, pandangan-pandangan setempat (local) yang bersifat bijaksana, penuh kearifan, bernilai baik, yang tertanam dan diikuti oleh anggota masyarakatnya. Nilai budaya yang berkembang dalam suatu masyarakat, akan selalu berakar dari kearifan tradisional (kearifan lokal) yang muncul dan berkembang sejalan dengan perkembangan masyarakat itu sendiri, keanekaragaman masyarakat Indonesia dengan ciri kemajemukan budayanya tidak bisa secara otomatis terintegrasi menjadi kebudayaan nasional, yang sama mantapnya dengan setiap sistem adat yang ada, karena kebudayaan nasional tersebut baru pada taraf pembentukan. Dengan berpijak pada pemahaman tersebut, nampak bahwa kebijakan pendidikan yang sentralistik menjadi tidak relevan. Strategi pendidikan yang berbasis budaya, dapat menjadi pilihan karena pendidikan berbasis adat tidak akan melepaskan diri dari prinsip bahwa manusia adalah faktor utama, sehingga manusia harus selalu merupakan subyek sekaligus tujuan dalam setiap langkah dan upaya perubahan. 


\section{Pembudayaan Nilai Dasar Negara Pancasila}

Demi tegaknya integritas NKRI dan visi-misi nation and character building, maka seluruh komponen bangsa berkewajiban untuk mampu meningkatkan wawasan nasional agar SDM warga negara kita (khususnya generasi muda), senantiasa mewaspadai tantangan: globalisasi-liberalisasi dan postmodernisme. Juga tantangan nasional dalam era reformasi (yang memuja kebebasan atas nama demokrasi dan HAM), dalam praktik menjadi budaya neoliberalisme dan anarchisme, yang mengancam integritas bangsa dan NKRI sebagai sistem kenegaraan Pancasila. Cukup mendesak program pendidikan dan pembudayaan nilai dasar negara Pancasila sebagai bagian dari visi-misi nation and character building; terutama dalam meningkatkan mental-moral manusia dan warga negara RI sebagai satu bangsa Indonesia dalam NKRI sebagai negara bangsa (nation state, negara kebangsaan) seutuhnya. Maknanya, kondisi warisan budaya daerah dan kearifan lokal sebagai kebhinnekaan (pluralisme) dalam nusantara secara kultural dan moral ditingkatkan menjadi bangsa Indonesia. Jadi, pluralisme dan warisan keunggulan daerah (kearifan lokal), ditingkatkan dalam puncak budaya dan semangat kebangsaan dalam integritas nasional: kesatuan nasional (tunggal ika) dan kebanggaan nasional. Inilah jiwa kebangsaan dan jiwa nasional Indonesia yang melembaga dalam NKRI berdasarkan Pancasila - UUD 1945. Bandingkan dengan motto negara Amerika Serikat: E Pluribus Unum.

Bangsa Indonesia adalah bagian dari tatanan peradaban dunia modern dalam semangat persahabatan dan kerjasama demi kemerdekaan, perdamaian abadi dan keadilan sosial. Dunia abad XXI ditandai era globalisasi - liberalisasi dan postmodernisme (pasca modernisme), bahkan ideologi yang berbasis keagamaan (carut marutnya beberapa negara di Jazirah Arab dan Afghanistan). Dunia demikian menjadi medan adu kekuatan. Negara adidaya, dipelopori Amerika Serikat dan Uni Eropa bergerak pesat merebut supremasi (keunggulan) politik, ekonomi, budaya dan ipteks serta militer (hankam). Kita menyaksikan bagaimana USA dan Uni Eropa bersama negara-negara industri maju lainnya (Jepang, RRC, Korsel, Australia) terus mendominasi politik dan ekonomi dunia. Kapitalisme - liberalisme menggoda dan melanda dunia.

Semua komponen bangsa bersama Pemerintah, khususnya para generasi muda dan lembaga-lembaga tinggi negara berkewajiban untuk membendung pengaruh, tantangan dan ancaman globalisasi-liberalisasi dan postmodernisme di atas, demi penyelamatan masa depan bangsa dalam integritas sistem kenegaraan Pancasila. Kewajiban demikian merupakan amanat nasional dan amanat moral, karena ajaran paham dari sistem ideologi mereka tidak sesuai, bahkan bertentangan dengan ajaran sistem ideologi kita (ideologi negara Pancasila). Karena, secara mendasar dan mendesak negara berkewajiban meningkatkan pendidikan nasional sebagai kelembagaan pembudayaan nilai dasar negara Pancasila.

Tegaknya asas dan fungsi Pembudayaan dalam Fungsi Kelembagaan Negara di atas mutlak dilandasi, dipersiapkan dan dididik-kan bagi SDM warga negara sebagai subyek pengelola sistem kenegaraan Pancasila, melalui pendidikan nilai dasar negara Pancasila dan UUD 1945 secara signifikan. Sebaliknya, terlaksananya pendidikan nilai dasar negara Pancasila, berkat mantapnya kebijaksanaan kepemimpinan dan kelembagaan nasional yang mengemban amanat sistem kenegaraan Pancasila dan UUD 1945. Mulai konsepsi sistem 
nasional yang terpercaya (berkembang dinamis), sampai pelaksanaan atau praktiknya, sesungguhnya adalah proses pembudayaan yang efektif dan berdaya guna.

\section{Membangun Bangsa Berkarakter}

Bangsa Indonesia harus memulai babak baru dimana penjajahan dan penindasan dengan alasan apapun tidak dapat dianulir dari negeri ini. Begitupun juga dengan payung-payung keadilan harus ditegakkan. Setelah sekian lama, proklamasi dikumandangkan tetapi sampai sekarang bangsa ini masih belum terlepas dari penjajahan dan penindasan. Memang kita sudah tidak terjerat lagi terhadap kolonial penjajah Portugis, Inggris, Belanda, atau Jepang. Tetapi kita masih dijajah oleh bangsa kita sendiri. Siapa sangka justru penjajahan bangsa sendiri lebih berbahaya dari pada penjajahan yang dilakukan oleh bangsa lain. Penjajahan oleh bangsa sendiri akan merongrong sendi-sendi keadilan berbangsa dan bernegara, melemahkan sistem kenegaraan, menurunkan tingkat kualitas hidup dan menjadikan masyarakat sebagai budak di negeri sendiri. Pembangunan yang seharusnya menggusur kemiskinan, justru malah menggusur orang-orang miskin. Bermunculannya plaza, square dan ritel-ritel seperti: Indomaret dan Alfamaret serta bermunculannya produk makanan yang berbau asing (luar negeri) seperti KFC, CFC, McDonald, Pizzahutt, Hamburger, menunjukkan semakin terpinggirnya pasar tradisional dan produk lokal.

Budaya masyarakat kita mulai direcoki oleh budaya-budaya asing, sehingga karakter dan kearifan lokalnya luntur tergerus oleh sistem kapitalisme dan kepemimpinan yang berpola majikan-buruh. Kondisi ini jelas menunjukkan adanya penjajahan oleh bangsa sendiri. Bangsa kita telah dijajah oleh produkproduk asing, kita dibiarkan menjadi bangsa yang konsumtif, bangsa yang menjadi "buruh" dinegeri sendiri. Hingga saat ini kita belum sadar akan bentuk penjajahan baru yang sangat terkenal dengan sebutan Neoliberalisme dan Komunis Gaya Baru. Penjajahan ini bisa kita klasifikasikan kedalam 6 bagian, yaitu: (1) penjajahan hukum; (2) penjajahan politik; (3) penjajahan ekonomi; (4) penjajahan kesehatan; (5) penjajahan pendidikan; dan (6) penjajahan HAM.

Tidak perlu diuraikan sejauhmana penjajahan ini karena kita semua sudah menyadari dan mengetahui hampir setiap hari dimedia-media baik media cetak maupun elektronik. Tetapi yang pasti adalah yang menjadi korban dari ini semua adalah rakyat miskin yang semakin lama semakin sengsara. Wong cilik lungguh dingklik, ancik-ancik mripate mlilik, yen perlu ben mati dhisik. Kita harus mencari solusi, para generasi muda harus tanggap dan menjadi gardha terdepan, sehingga semua jenis penjajahan ini bisa dihapuskan dari bumi Pancasila ini. Pangkal dari permasalahan ini adalah hilangnya rasa humanisme dan terkikisnya karakter dan budaya bangsa Indonesia. Seandainya para pemegang wewenang dalam setiap lembaga dapat melakukan tugasnya sesuai dengan fungsi dan hati nuraninya tentu penyelewengan dan segala bentuk penyalahgunaan wewenang tidak akan terjadi. Selain itu juga dibutuhkan karakter dan sikap yang tegas untuk mengatakan tidak atas segala bentuk kemungkinan yang mengindikasikan terhadap penyalahgunaan wewenang. Sehingga dengan demikian hal-hal yang berkaitan dengan penyalahgunaan wewenang akan dapat dihindari.

Seharusnya sudah menjadi perhatian kita bersama mengenai pentingnya memupuk sikap humanisme serta memperbaiki karakter bangsa indonesia yang 
telah pudar ini. Oleh sebab itu, kita masih mempunyai kesempatan serta masa depan dengan mendidik generasi masa depan dengan nilai-nilai humanisme yang luhur serta mempunyai karakter yang bersih dan mulia. Pendidikan karakter merupakan aspek dominan dalam wilayah ini. Karakter bangsa terbangun atau tidak sangat tergantung kepada bangsa itu sendiri. Bila bangsa tersebut memberikan perhatian yang cukup untuk membangun karakter maka akan terciptalah bangsa yang berkarakter. Bila negara kita dapat memberikan pembangunan karakter kepada para warga negara sejak dini, maka akan tercipta pula generasi yang berkarakter dan berwawasan kebangsaan yang luas melalui penghayatan dan pengamalan Pancasila. Demikian pula sebaliknya. Kita faham, bahwa Tuhan tidak merubah keadaan suatu kaum bila mereka tidak berusaha melakukan perubahan itu (innalloha laa yughoyyiru maa biqoumin hattaa yughoyyiruu maa bi anfusihim). Lima pilar karakter luhur bangsa Indonesia mencakup:

a. Transendensi: Menyadari bahwa manusia merupakan ciptaan Tuhan yang maha Esa. Dari kesadaran ini akan memunculkan sikap penghambaan sematamata pada Tuhan yang Esa. Kesadaran ini juga berarti memahami keberadaan diri dan alam sekitar sehingga mampu menjaga dan memakmurkannya. Ketuhanan yang maha Esa;

b. Humanisasi: Setiap manusia pada hakikatnya setara di mata Tuhan kecuali ilmu dan ketakwaan yang membedakannya. Manusia diciptakan sebagai subjek yang memiliki potensi. Kemanusiaan yang adil dan beradap;

c. Kebinekaan: Kesadaran akan adanya sekian banyak perbedaan di dunia. Akan tetapi, mampu mengambil kesamaan untuk menumbuhkan kekuatan, Persatuan Indonesia;

d. Liberasi: Pembebasan atas penindasan sesama manusia. Karenanya, tidak dibenarkan adanya penjajahan manusia oleh manusia. Kerakyatan yang dipimpin oleh hikmah kebijaksanaan dalam permusyawaratan perwakilan;

e. Keadilan: Keadilan merupakan kunci kesejahteraan. Adil tidak berarti sama, tetapi proporsional. Keadilan sosial bagi seluruh rakyat Indonesia.

Sukamto (2009) mengemukakan bahwa untuk melakukan pendidikan karakter, perlu adanya powerfull ideas, yang menjadi pintu masuk pendidikan karakter. Powerfull ideas ini meliputi: (1) god, the world dan me (gagasan tentang Tuhan, dunia, dan saya); (2) knowing yourself (memahami diri sendiri); (3) becoming a moral person (menjadi manusia bermoral); (4) understanding and being understood getting along with others (memahami dan dipahami); (5) a sense of belonging (bekerjasama dengan orang lain); (6) drawing strength from the past (mengambil kekuatan di masa lalu); (7) dien for all times dan places; (8) caring for Allah's creation (kepedulian terhadap makhluq); (9) making a difference (membuat perbedaan); dan (10) taking the lead.

Adapun nilai-nilai luhur yang perlu diajarkan agar menjadi sikap hidup sehari-hari menurut Sukamto, meliputi: kejujuran; loyalitas dan dapat diandalkan; hormat; cinta; ketidakegoisan dan sensitifitas; baik hati dan pertemanan; keberanian; kedamaian; mandiri dan potensial; disiplin diri dan moderasi; kesetiaan dan kemurnian; dan keadilan dan kasih sayang. Seorang intelektual hendaknya berkarakter kenabian/profetik (berjiwa agama) memiliki sifat-sifat sebagai berikut: karakter manusia "sempurna" sebagaimana ditampilkan oleh para 
Nabi dalam kehidupan sehari-hari. Bila seseorang memahami akhlak para nabi (sejak Nabi Adam sampai dengan Nabi Muhammad SAW) dan turut mengamalkannya dalam kehidupan sehari-hari berarti orang tersebut telah memiliki karakter. Jadi karakter yang harus dibangun adalah karakter yang baik, bila tidak niscaya yang berkembang adalah karakter yang tidak baik ( $F a$ alhamaha fujuroha wa taqwaha. Qod aflaha man zakkahaa, wa qod khoba man dassaha).

Agar dapat memiliki karakter profetik maka 3 aspek utama dalam diri manusia harus diberikan perhatian secara seimbang, yakni: hati, emosi, dan akal. Nabi bersabda: Ketahuilah bahwa dalam diri setiap kalian ada "mudghoh" (segumpal daging), jika mudghoh itu bersih maka semua yang ditampilkan oleh orang tersebut juga bersih (baik), dan jika mudghoh itu rusak maka yang ditampilkan oleh orang tersebut juga rusak (tidak baik). Ketahuilah bahwa yang disebut mudghoh itu adalah al-qolb (hati). Beberapa faktor penting sebagai ciri karakter profetik, yakni:

a. Sadar sebagai makhluq ciptaan Tuhan: sadar sebagai makhluq muncul ketika ia mampu memahami keberadaan dirinya, alam sekitar, dan Tuhan YME. Konsepsi ini dibangun dari nilai-nilai transendensi;

b. Cinta Tuhan: orang yang sadar akan keberadaan Tuhan meyakini bahwa ia tidak dapat melakukan apapun tanpa kehendak Tuhan. Oleh karenanya memunculkan rasa cinta kepada Tuhan. Orang yang cinta Tuhan akan menjalankan apapun perintah dan menjauhi larangan-Nya;

c. Bermoral: jujur, saling menghormati, tidak sombong, suka membantu, dll merupakan turunan dari manusia yang bermoral;

d. Bijaksana: karakter ini muncul karena keluasan wawasan seseorang. Dengan keluasan wawasan, ia akan melihat banyaknya perbedaan yang mampu diambil sebagai kekuatan. Karakter bijaksana ini dapat terbentuk dari adanya penanaman nilai-nilai kebinekaan;

e. Pembelajar sejati: untuk dapat memiliki wawasan yang luas, seseorang harus senantiasa belajar. Seorang pembelajar sejati pada dasarnya dimotivasi oleh adanya pemahaman akan luasnya ilmu Tuhan (nilai transendensi). Selain itu, dengan penanaman nilai-nilai kebinekaan ia akan semakin bersemangat untuk mengambil kekuatan dari sekian banyak perbedaan;

f. Mandiri: karakter ini muncul dari penanaman nilai-nilai humanisasi dan liberasi. Dengan pemahaman bahwa tiap manusia dan bangsa memiliki potensi dan sama-sama subjek kehidupan maka ia tidak akan membenarkan adanya penindasan sesama manusia. Darinya, memunculkan sikap mandiri sebagai bangsa;

g. Kontributif: kontributif merupakan cermin seorang pemimpin.

\section{KESIMPULAN}

Modernisasi sebagai bentuk perubahan sosial merupakan konsekuensi logis dari kondisi dunia yang semakin mengglobal. Globalisasi merupakan konsep yang banyak digunakan untuk merespon kondisi dunia yang tanpa batas atau sekat. Salah satu realitas yang harus selalu dikritisi untuk menyikapi globalisasi adalah bahwa globalisasi dengan modernisasi ternyata telah menggerus bahkan telah mematikan nilai-nilai kearifan lokal suatu daerah. Melalui proses globalisasi telah sedikit demi sedikit mengubah prespektif, gaya hidup, dan perilaku individu, 
dan disadari atau tidak, globalisasi telah mengikis nilai-nilai humanisme, ikatan, dan hubungan sosial. Oleh karena itu pembentukan karakter dilakukan secara sistematis dan berkesinambungan, serta melibatkan aspek: knowledge, feeling, loving, dan acting. Pembentukan karakter dapat diibaratkan sebagai pembentukan seseorang menjadi body builder (binaragawan) yang memerlukan "latihan otototot akhlak" secara terus-menerus agar menjadi kokoh dan kuat. Mengingat pentingnya penanaman karakter di usia dini dan mengingat usia prasekolah merupakan masa persiapan untuk sekolah yang sesungguhnya, maka penanaman karakter yang baik perlu dimulai sejak anak usia dini / prasekolah.

Selanjutnya dalam rangka Membangun Pendidikan Karakter Bangsa Melalui Budaya Kerarifan Lokal perlu dilakukan pengkajian, dan pengembangan karakter dengan fokus menanamkan 9 pilar nilai-nilai luhur universal: (1) cinta Tuhan dan alam semesta beserta isinya; (2) tanggung jawab, kedisiplinan, dan kemandirian; (3) kejujuran; (4) hormat dan santun: (5) kasih sayang, kepedulian, dan kerjasama; (6) percaya diri, kreatif, kerja keras, dan pantang menyerah; (7) keadilan dan kepemimpinan; (8) baik dan rendah hati; dan (9) toleransi, cinta damai dan persatuan. Pilar akhlak (moral) yang dimiliki (mengejewantah) dalam diri seseorang sehingga ia menjadi orang yang berkarakter baik (good character) adalah: jujur, sabar, rendah hati, tanggung jawab, dan rasa hormat.

Karakter tersebut tercermin dalam kesatuan organisasi/sikap yang harmonis dan dinamis. Tanpa nilai-nilai moral dasar ini (basic moral values) yang senantiasa mengejewantah dalam diri pribadi kapan dan dimana saja, orang dapat dipertanyakan kadar keimanan dan ketaqwaan. Ciri orang yang kuat imannya, adalah: (1) secara tulus dia patuh pada Tuhan-nya; (2) dia tertib dan disiplin melaksanakan perintah dan menjauhi larangan Tuhan, secara mahdhoh/ritual; (3) memahami dan menghargai ajaran agama lain, sehingga tercipta kehidupan yang toleran; dan (4) memperbanyak kerjasama dalam bidang kehidupan sosial budaya. Tatanan sosial dan tradisi lokal yang berakar kuat akan memberikan sentuhan halus yang mengingatkan manusia agar tidak terbawa arus perubahan yang demikian dahsyat. Nilai budaya yang berkembang dalam suatu masyarakat, akan selalu berakar dari kearifan tradisional yang muncul dan berkembang sejalan dengan perkembangan masyarakat itu sendiri, kemajemukan masyarakat Indonesia dengan ciri keragaman budayanya tidak bisa secara otomatis terintegrasi menjadi kebudayaan Nasional, yang sama mantapnya dengan setiap sistem adat yang ada, karena kebudayaan Nasional tersebut baru pada taraf pembentukan.

Sebagai bahan renungan agar kita lebih ingat tugas mulia seorang guru mari kita simak pendapat Ghozali yang menyatakan: wujud yang paling mulia di permukaan bumi ini adalah jenis manusia. Dan bagian yang paling mulia dari hakikat manusia adalah hatinya. Guru bekerja menyempurnakan, membesarkan, membersihkan dan menggiring hati mendekat kepada Allah Swt. Maka pangkat yang manakah yang lebih terhormat daripada hamba itu menjadi perantara antara Tuhan dengan mahluk-Nya dan kelak akan digiringnya ke surga Al Ma'wa. 


\section{DAFTAR RUJUKAN}

Djatmiko, H. E. 2006. Revolusi Karakter Bangsa Menurut Pemikiran Soeparno. Jakarta: Yayasan Obor Indonesia.

Elkind, D., dan Sweet, F. 2004. Character Education. New York: Bantam Books.

Foerster, F. W. 1966. Character Educational and Spiritual Ethic. Ghoete Institut.

Ghozali, I. 1991. An Integrated Education System in a Multifaith and Multicultural Country. Malaysia: Muslim Yuth Movement Malaysia.

Koesoema, A. 2010. Pendidikan Karakter. Jakarta: Grasindo.

Lickona, T. 1992. Educating for Character: How Our Schools can Teach Respect and Responsibility. New York: Bantam Books.

McCoubrey, dan White, N. D. 1996. Textbook on Jurisprudence. Glasgow: Bell dan Bain Ltd.

Murphy, J. G., dan Coleman, J. L. 1990. Philosophy of Law an Introduction to Jurisprudence. San Francisco: Westview Press.

Sedyawati, E. 2007. Keindonesiaan dalam Budaya: Buku 1 Kebutuhan Membangun Bangsa yang Kuat. Jakarta: Wedatama Widya Sastra.

Sedyawati, E. 2008. Keindonesiaan dalam Budaya: Buku 2 Dialog Budaya Nasional dan Etnik, Peranan Industri Budaya dan Media Massa, Warisan Budaya dan Pelestarian Dinamis. Jakarta: Wedatama Widya Sastra.

Smiers, J. 2009. Arts under Pressure: Memperjuangkan Keanekaragaman Budaya-budaya di Era Globalisasi. Terjemahan oleh Umi Haryati. Yogyakarta: Insist Press.

Syam, M. N. 2007. Penjabaran Fislafat Pancasila dalam Filsafat Hukum Sebagai Landasan Pembinaan Sistem Hukum Nasional). Malang: Laboratorium Pancasila UM.

Zuhdi, D. 2009. Pendidikan Karakter: Grand Design dan Nilai-nilai Target. Yogyakarta: UNY Press. 